\title{
The Theological Thought of Fazlur Rahman: A Modern Mutakallim
}

\author{
Ahad M. Ahmed
}

Kuala Lumpur: Islamic Book Trust, 2017. 284 pages.

Reading the book under review has truly taken me down memory lane. Some 20 years ago I encountered the academic study of Islam primarily 
through reading the books of Professor Fazlur Rahman (including the 'Serbo-Croatian' translation of his book Islam) all of which left a deep and indelible impression on me both as a Muslim and as an aspiring academic. In that sense I wish I had myself authored this or a similar book.

Generally speaking, Ahmed appraises and frames the theological thinking of Rahman from the perspective of considering him a significant contributor to the "Islamic theology of modernity" (jadid 'ilm al-kalam) in the tradition of Muhammad Iqbal, the famous twentieth-century philosopher of the Subcontinent (xiv-xv). Rightfully so, this reviewer would add! The main aim the author sets himself in the book is to "scrutinise" Rahman's contribution to traditional kalam, theology proper (ilähiyāt), and prophecy (nubuwwat) but with an eye on assessing the implications Rahman's theological thought has on "modernization and reformation of "ilm ul kalam" (xv). Methodologically, Ahmed considers his approach as falling in line with "the constructivist method" associated with Albert Hourani's Arabic Thought in the Liberal Age (1967), "wherein the emphasis is placed on the importance of locating ideas within their unique intellectual context" and maximum attention is awarded to the influences, personality traits and circumstances that have had a bearing on the intellectual under analysis (xvi).

The book under review consists of an introduction and four chapters. The first chapter is a biographical overview of Rahman's life and his major works. It also helpfully positions Rahman's ideas in the context of his two major interlocutory traditions, namely, what the author of the book terms (perhaps problematically) as Orientalism and Islamic orthodoxy. Finally, the chapter provides an outline of the intellectual "sources" of Rahman's Islamic thought (Qur'an, Sunna, ijmā', and ijtihād) with special attention given to how his approach to these sources plays out in relation to major issues in Islamic intellectual history including the conceptual, epistemological, and hermeneutical relationship between the concepts of hadith and Sunna and his position on the issue of the closing of the gates of ijtihād.

Drawing upon Rahman's work Revival and Reform and Islam and Modernity in particular, Ahmed in the second chapter examines Rahman's thinking on the issues pertaining to the emergence and the development of Islamic theology (kaläm) and the major debates that have animated them (e.g., isläm and imān; qadar and jabr, irjä, al-husn wa-l-qubh) and the role of the major theological groups and scholars in the development of Sunni theology during the formative and post-formative stages of kalām and up to the modern period. Here Ahmed argues that Rahman's analytical meth- 
od is to seek "a synthesis between Modern Orientalist methodology and the history of kalam literature" (71), which is also evident in other aspects of Rahman's Islamic thought-especially in his views on the nature and scope of the concept of Sunna and its relationship with the hadith literature.

Chapter three, titled "Concept of God," is dedicated to Rahman's conceptualization of what constitutes an Islamic worldview and the necessary approach for arriving at it. Ahmed argues that Rahman's thematic and contextualist approach to the Qur'an and his dynamic concept of Sunna are the only sources he considers as normative in formulating such a worldview. In this respect Ahmed paints a picture of Rahman's theology as having affinities with ideas underpinning liberation theology, with its emphasis on orthopraxy, God's concern for the poor and the marginalized, and the creation of a just (socio-economic) order. As such, Rahman's Qur'anic worldview, for Ahmed, points to the essentially ethical nature of the Islamic message. I fully concur with this assessment. The chapter also positions Rahman's thought on the concept of God in relation to major ideas developed by Islamic philosopher-jurists and mystics (Sufis). Ahmed, in this respect, argues that some of Rahman's ideas were influenced by those of Ibn Sina (on whom he wrote his doctoral dissertation) but that in essence Rahman's concept of God was different from that of both the Islamic philosopher-jurists and Sufis. For Rahman, in Ahmed's view, the concept of God was that of "a God of creativity" (158).

In the final chapter, Rahman's theory of prophethood takes front stage. Ahmed argues that the roots of Rahman's theory of prophethood are to be found in the thinking of Ibn Sina, with important modifications and additions rendering theology on equal footing with philosophy (218). Ahmed also describes Rahman's thinking on related issues such as historical debates on the doctrine of miracles and prophetic infallibility.

The book importantly brings into discussion in one volume all of the main topics that Rahman wrote on during the course of his life, and provides an informed discussion of Rahman's thinking as well as the major influences on his thought. Moreover, the author has also more or less successfully contextualized Rahman's thinking both in relation to Islamic intellectual history and the context in which Rahman himself wrote and worked (though as with all other books of this nature and scope, I am sure that specialists may take issue with how Ahmed interprets Rahman's views). However, in this respect, the reviewer considers that no justice was done to the reception of Rahman's ideas in the writings of Muslim and non-Muslim scholars who engaged with his ideas from the 1990s through the present. For example, 
one could mention the ideas of Abdullah Saeed (e.g., Reading the Qur'an in the Twenty-First Century, 2014) on contextualizing the Quran, inspired by Rahman's work on the interpretation of Qur'anic ethico-legal injunctions; that of Amina Wadud (The Qur'an and Woman, 1999) and Asma Barlas (Believing Women in Islam, 2002) on producing gender-egalitarian interpretations that are rooted in Rahman's double movement theory; some of my ideas on the nature and the scope of the concept of Sunna ("The Relative Status of Hadith and Sunna," 2014) that build further on those of Rahman; and the work of other twenty-first century progressive Muslim scholars like Ebrahim Moosa and Muqtedar Khan. This of course could fill another full book but at least warranted mention here. I hope the author will consider writing a separate volume on this topic.

The writing style is, at times, awkward, in part due to the book's primarily descriptive orientation, for the author is often referring to the ideas of others discussed by Rahman in his own work (so that the voices of different authors are sometimes confused). Occasional typos are present too. I would recommend this book to all those interested in Islamic intellectual history at less advanced levels and of course those who are keen to get a broad overview of the theological thinking of one of the most important Muslim academics and intellectuals of the twentieth century. However, I would still recommend a direct engagement with Rahman's works.

Adis Duderija, $\mathrm{PhD}$

Lecturer, Study of Islam and Society

Griffith University 